\title{
BIODIVERSITY AND REMOTELY SENSED HABITAT TYPES: A COMPaRison OF MONTANE MEAdOWS IN THE GALLATIN RANGE, MT AND IN Grand Teton National PaRk, WY
}

\author{
DIANE M. DEBINSKI $\downarrow$ DEPARTMENT OF ANIMAL ECOLOGY \\ IOWA STATE UNIVERSITY $\downarrow$ AMES \\ KELLY KINDSCHER $\downarrow$ KANSAS BIOLOGICAL SURVEY \\ UNIVERSITY OF KANSAS $\downarrow$ LAWRENCE \\ MARK E. JAKUBAUSKAS $\downarrow$ DEPARTMENT OF GEOGRAPHY \\ UNIVERSITY OF OKLAHOMA $\uparrow$ NORMAN
}

\section{$\downarrow \quad$ INTRODUCTION}

During the last decade, many approaches to biodiversity analysis have relied on the use of GIS (Geographic Information Systems) and remotely sensed data to categorize habitats, and then predict species assemblages expected to be found in those habitats. For example, Gap analysis uses predictions based on knowledge of the geographical limits of a species' distribution, ecological limiting factors, and habitat preferences (Scott et al. 1993). The goal of Gap analysis is to compare locations of plant and animal habitats to those of existing preserves, thereby identifying geographical gaps in habitat and/or species protection. One problem with this approach to conservation planning is that Gap analysis has not been extensively tested to determine the accuracy of its predictions (Flather et al. 1995).

Thus, an important parallel approach to Gap analysis, which we describe here, involves assessing statistical relationships between species distribution patterns and remotely sensed habitat types. For the past several years, we have used plants and butterflies as taxonomic test groups to examine these relationships. Because the plant species with dominant cover play a major role in determining the spectral reflectance patterns recorded by multispectral scanners, we felt that it was imperative to test the relationship between the remotely sensed habitat types and the plant community. Butterfly species were chosen because they are moderately host-specific insects, and their diversity may be correlated with underlying plant diversity. We have found that many of the butterfly and plant species of montane meadow communities show significant differences in distribution among remotely sensed habitat types (Debinski 1996, Jakubauskas et al. 1996).

Here, we pose the question whether species-habitat relationships (based on remotely sensed habitat categorization of montane meadows) in one part of the Greater Yellowstone Ecosystem will hold in another area of the ecosystem. The long-term goal of our research is to use known species-habitat relationships to predict species 
distribution patterns in unsurveyed sites. The test of geographic limits of species-habitat relationships is the first step in our analysis. More extensive data will be collected during 1997-1998, allowing for a more rigorous comparisons.

\section{$\downarrow \quad$ STUDY AREA}

The study areas for this research project included a 32,000 ha. area in the Gallatin and Madison Ranges (hereafter referred to as the Gallatins) and a similar size area in Grand Teton National Park (hereafter referred to as the Tetons). Meadow habitat types within the ecosystem range from hydric willow (Salix spp.) and sedge (Carex spp.) meadows to high-altitude tundra and rock meadows (Knight, 1994). The Greater Yellowstone Ecosystem was chosen because it is one of the largest intact ecosystems in the continental U.S., and species/habitat relationships were therefore expected to be less affected by human disturbance.

\section{$\downarrow \quad$ METHODS}

The methodology for this study was directed toward producing maps of spectrally distinct meadow vegetation classes similar to those produced for Gap analysis. Landsat Thematic Mapper (TM) data are being used for vegetation mapping in the majority of state Gap analysis projects. TM data records reflected light in six spectral bands (blue, green, red, near-infrared, and two mid infrared), with spatial resolution of $30 \mathrm{~m}$ and on a scale of 0 255 ( 0 indicates no light reflected by the object and 255 is maximum separation). The red and infrared bands of TM data have been found to be particularly useful for vegetation mapping.

Satellite data of the study areas were converted from brightness values to units of radiance (mW/cm2/sr/um) (Markham and Barker 1986) and georeferenced to a Universal Transverse Mercator (UTM) coordinate system. To identify areas with similar spectral reflectance characteristics, an iterative euclidean distance clustering algorithm was applied to create preliminary spectrally distinct classes. Spectral classes were identified and assigned to a specific vegetation (or non-vegetation) class with the aid of aerial photos, U.S. Forest Service stand survey maps, and personal knowledge of the study area.
Non-vegetated areas (e.g., water bodies, roads, developed areas) were not included in the final vegetation map. In the Gallatins, the meadow classes were defined along an apparent moisture gradient from wet sedge meadow (M1) to dry grassland with sagebrush (M6). In the south (Tetons), the meadows were characterized from M1-M7 because the driest meadow was slightly different from those in the north. The M4 meadow type was discarded in the Tetons because it was found to represent pasture land. Thus, the classes correspond between the north and the south except for M7 meadow which was absent in the north and the M4 meadow which was absent in the south.

Since class polygons smaller than 1 ha would be difficult to locate with confidence in the field, the final vegetation map was generalized to a minimum mapping unit of 1 ha (approximately 11 TM pixels). To facilitate location of study sites during fieldwork, the map was plotted on translucent Mylar, allowing overlays onto 1:24,000 topographic maps of the study region. We inventoried five spatially distinct examples of each of the M1-M6 habitats in the Gallatins in 1993-95 and five spatially distinct examples of M1-M3 and M5-M7 habitats in the Tetons in 1996 (total sites = 60). Sample sites were located in the field with the aid of aerial photography, 1:24,000 USGS topographic maps, a global positioning device, and compass readings from identifiable landmarks.

\section{SPECIES AND HABITAT CHARACTERIZATION IN SAMPLE SITES}

Meadow vegetation was surveyed in $20 \mathrm{x}$ $20 \mathrm{~m}$ plots. The Gallatins were surveyed in 1995 and the Tetons were surveyed in 1996. Each plot was surveyed for total coverage on a per species basis for all grasses, forbs, and shrubs. Plant taxonomy followed Dorn (1984). Species cover was determined by visually estimating the sum of the greatest spread of foliage for each species in each plot (Daubenmire 1959). In cases where species identification was problematic due to the seasonal sampling time or taxonomic difficulties, species were lumped by genus to calculate a total cover for the genus rather than the species.

Presence/absence data were collected for butterflies in the Gallatins during 1993 and 1995 and in the Tetons in 1996. Butterflies were surveyed on sunny days from 1000-1630 hrs. employing previously developed methods (Debinski 
and Brussard 1992). Taxonomy followed Scott (1986). Surveys were conducted for $20 \mathrm{~min}$. periods by netting and releasing in $50 \times 50 \mathrm{~m}$ plots. Surveys were repeated a minimum of three times at each site in the Gallatins. In the Tetons, surveys were conducted for 30 minutes, but replicated only twice due to a limited field season. Stepwise discriminant analysis of the butterfly data was conducted by using a modified presence/absence matrix that weighted the number of species occurrences relative to the number of times a site was surveyed. Each species/site combination was scored as $\mathrm{p}_{\mathrm{ij}}=\mathrm{m}_{\mathrm{ij}} / \mathrm{n}_{\mathrm{j}}$, where $\mathrm{m}_{\mathrm{ij}}$ is the number of occurrences for species $i$, and $n_{j}$ is the total number of samples taken at site $\mathrm{j}$.

\section{RESULTS}

Analysis of the grass, forb, and shrub cover data revealed similarities in the major genera, but large differences in species distribution patterns between the Gallatins and the Tetons. There were also major differences among meadow types within each region. Vegetation characterizing M1 and M2 meadows in both areas included Carex spp. and Juncus spp. and there was often some standing water. M1 meadows in the Tetons were dominated bay Salix spp. M2 meadows in both areas had a high cover of Poa spp. M3 meadows in the Gallatins were characterized by high cover of Salix spp. and Fragaria spp. and tended to be located near streams; in the Tetons, Poa pratensis and Artemesia tridentata were more common. M4 meadows were only surveyed in the Gallatins. They were of medium moisture with Stipa richardsonii, Bromus spp., and mixed herbaceous vegetation (e.g., Potentilla spp., Lupinus argenteus, Geum triflorum, and Geranium spp.). M5 meadows in both the Gallatins and Tetons had a mixture of Artemesia tridentata, Agropyron spp., and mixed herbaceous vegetation. M6 meadows in both areas were characteristically xeric, rocky, and dominated by Artemesia tridentata, Festuca spp., and bare ground. In the Gallatins, this meadow type tended to occur on south-facing slopes, whereas in the Tetons, it was found on large, open flats. M7 meadows were only found in the Tetons on highly eroded, steep slopes. The major cover species were Agropyron spp. and Artemesia tridentata.

Overall, the 30 sites sampled in the Gallatins yielded 193 total plant species, whereas
160 species were found in the Tetons. For each of the meadow types that were in common (M1, M2, M3, M5, M6), there were a larger number of plant species found in the Tetons (Table 1). It was difficult to conduct statistical analyses of the plant communities due to the fact that while genera were often similar, most of the species were different by M-type in the Gallatins versus the Tetons. For example, M1's in both the Gallatins and the Tetons had Scirpus sp., Carex sp., Salix sp., and Poa sp. comprising a major portion of the coverage. However, the species differed between the areas and the species with the highest cover also differed between areas.

Table 1. Comparison of total species richness of grasses, shrubs, and forbs by meadow type between the Gallatins and the Tetons. Meadow types range from M1 (hydric) to M7 (xeric). The M4 class did not exist in the Tetons and the M7 class did not exist in the Gallatins, so the species richness in each of these categories is a blank.

\begin{tabular}{|c|c|c|c|}
\hline Meadow Type & Tetons & (1996) & Gallatins (1995) \\
\hline M1 & 48 & & 27 \\
\hline M2 & 69 & & 39 \\
\hline M3 & 85 & & 36 \\
\hline M4 & - & & 34 \\
\hline M5 & 88 & & 35 \\
\hline M6 & 53 & & 29 \\
\hline M7 & 72 & & - \\
\hline Total & 160 & & 193 \\
\hline
\end{tabular}

A total of 42 butterfly species were observed during the surveys in the Gallatins and the Tetons. However, only $28(67 \%)$ of these species were seen in both sites (Table 2). Approximately one-third of the butterfly species in both sites showed significant differences in distribution among remotely sensed habitats, but less than half of these were the same species in both the north and the south (Plebejus saepiolus, Boloria selene, Euphydryas gillettii, and Coenonympha inornata). In the remaining cases, two species of the same genus often showed up as significant, but one species would show up in the Gallatins and another species of that same genus was significant in the Tetons. For example, Colias interior was significantly related to dry meadows in the Tetons, but Colias eurytheme was the species found to be correlated with medium moisture meadows in the Gallatins. Comparing M-types, we found that M3 meadows had the highest species richness and the highest similarity in species composition between 
the Gallatins and the Tetons. All meadows showed a Jaccard's similarity index for butterfly species between the Gallatins and Tetons of approximately 40\% (M1: 0.39, M2: 0.39, M3: 0.44, M4: 0.395, and M6: 0.382).

Table 2. Comparison of the butterfly species observed during 1993-1996 in the Gallatins and Grand Teton National Parks. Meadow types surveyed range from M1 (hydric) to M7 (xeric)..

\begin{tabular}{lll}
\hline Species & Grand Tetons & Yellowstone
\end{tabular}

Parnassius clodius

Pamassius phoebus

Papilio zelicaon

Papilio glaucus

Papilio eurymedon

Pieris occidentalis

Pieris napi

Colias interior

Anthocharis sara

Euchloe ausonia

Harkenclenus titus

Lycaena cupreus

Gaeides xanthoides

Lycaena heteronea

Lycaena helloides

Epidemia nivalis

Plebejus saepiolus

Plebejus icarioides

Plebejus acmon

Plebejus glandon

Plebejus melissa

Glaucopsyche lygdamus

Glaucopsyche piasus

Limenitis weidemeyerii

Nymphalis milberti

Charidryas palla

Phyciodes tharos

Phyciodes campestris

Euphydryas gillettii

Euphydryas editha

Boloria selene

Boloria epithore

Speyeria callippe

Speyeria egleis

Speyeria atlantis

Speyeria hydaspe

Speyeria mormonia

Speyeria cybele

Coenonympha haydenii

Coenonympha inomata

Cercyonis oetus

Erebia epipsodea

Pieris protodice

Colias eurytheme

Colias philodice

Colias pelidne

Lycaena mariposa

Euphilotes enoptes

Vanessa cardu'

Polygonia faunus

Boloria frigga $\mathrm{x}$

$\mathrm{X}$

$\mathrm{X}$

$\mathrm{X}$

$\mathrm{X}$

$\mathrm{X}$

$\mathrm{X}$

$\mathrm{X}$

$\mathrm{X}$

$\mathrm{X}$

$\mathrm{x}$

$\mathrm{X}$

$\mathrm{X}$

$\mathrm{X}$

$\mathrm{X}$

$\mathrm{X}$

$\mathrm{X}$

$\mathrm{X}$

$\mathrm{X}$

$\mathrm{X}$

$\mathrm{X}$

$\mathrm{X}$

$\mathrm{X}$

$\mathrm{X}$

$\mathrm{X}$

$\mathrm{X}$

$\mathrm{X}$

$\mathrm{X}$

$\mathbf{X}$

$\mathrm{X}$

$\mathrm{X}$

$\mathrm{x}$

$\mathrm{X}$

$\mathrm{x}$

$\mathbf{X}$

$\mathrm{X}$

$\mathrm{X}$

\begin{tabular}{|ll|}
\hline Oeneis uhleri & $\mathrm{X}$ \\
Vanessa atalanta & $\mathrm{X}$ \\
Nymphalis vau-album & $\mathrm{X}$ \\
Vanessa annabella & $\mathrm{X}$ \\
\hline
\end{tabular}

\section{DISCUSSION}

The comparisons of the two areas (Gallatins versus the Tetons) showed a moderate level of species similarity in both the plant and the butterfly community. However, the comparisons are confounded by the fact that the data were collected in different years. The implication is that some plant species could have been less visible, or certain butterfly species might not have been observed due to phenological differences in emergence time.

Plant identification was also better in 1996 than in earlier years because of lumping of certain genera (Bromus, Asters, Poa spp.), although this lumping was taken into consideration in the calculation of total plant species richness (i.e., Teton plant data were lumped accordingly in Table 1). Overall the data indicate that there is considerable diversity within each site and between areas. In comparisons on a species basis, it is obvious that genera with high coverage values (Festuca, Artemesia, Carex, Salix) in the Gallatins also had high coverage in the Tetons. However, for Carex and Salix spp., it may be different species within the genus that are dominant.

Some of the differences between butterfly communities in the Gallatins relative to the Tetons may be explained by a shorter sampling period in the southern sites. If we had had a longer field season in the Tetons, the similarity of the species lists would probably have been higher. For example, we probably missed seeing early-emerging species such as Anthocarus sara in the Tetons because we were not present to sample in the early summer season. However, given the fact that both sites had the same number of species despite a shorter sampling time in the Tetons, one would expect that if both sites were sampled with equal effort, species richness would be higher in the Tetons.

In summary, the species similarity of the butterfly communities within meadow types and between regions is approximately $40 \%$. The similarity of the plant community is probably within the same range as the butterflies, but we could not calculate a similarity coefficient from our data. It is 
not surprising that there are some differences, because the two areas are 120 miles apart, and the meadows in the Gallatins tend to be smaller in size than the Tetons. M3 meadows showed the highest species diversity in both areas and both taxonomic groups. The Teton meadows supported a higher diversity of plants and may support a higher diversity of butterfly species. Fieldwork in 1997 and 1998 will allow us to examine these differences more closely because we will sample both areas each year.

\section{ACKNOWLEDGEMENTS}

This research was supported by the University of Wyoming National Park Service Research Center, the University of Kansas General Research Fund and Panorama Society, and the Iowa State University Experiment Station. A. Vandiver, R. Krager, and N. Hallstrom of the Gallatin National Forest provided data, maps of the area, and housing. We thank J. Pritchard, L. Kelly, C. King, K. Horst, A. Trainer, R. Hurst, A. Fraser, M. Wieland, D. Slattery, and P. Rich, for assistance in the field, and S. White, A. Fraser, E. Hasler, and M. Mehaffey for assistance with data analysis.

\section{LITERATURE CITED}

Daubenmire, R.F. 1959. Canopy coverage method of vegetation analysis. Northwest Science 33:43-64.

Debinski, D.M. and P.F. Brussard. 1992. Biological diversity assessment in Glacier National Park, Montana: I. Sampling design. pp. 393-407 In: D.H. McKenzie, D.E. Hyatt, and V.J. McDonald (eds.) Proceedings from the International Symposium on Ecological Indicators. Elsevier Publishing, Essex, England.

Debinski, D.M. 1996. Using Satellite Data to Support Fieldwork: Can species distributions be predicted? Yellowstone Science 4(3):2-5.

Dorn, 1984. Vascular plants of Montana. Mountain West Publishing, Cheyenne, WY. $276 \mathrm{pp}$.
Flather, C.H., K.R. Wilson, D.J. Dean, and W.C. McComb. 1995. The National Gap Analysis Program: a review and inspection of ecological assumptions. A report to the National Council of the Paper Industry for Air and Stream Improvement, Inc.

Jakubauskas, M.E., D. M. Debinski, and K Kindscher. 1996. Integration of Multispectral and Ecological Data for Characterizing Montane Meadow Communities in the Greater Yellowstone Ecosystem. Proceedings of the 1996 International Geoscience and Remote Sensing Symposium, Lincoln, Nebraska.

Knight, D.H. 1994. Mountains and Plains: The Ecology of Wyoming Landscapes. Yale University Press, New Haven. 338 p.

Markham, B.L. and J.L. Barker. 1986. Landsat MSS and TM post-calibration dynamic ranges, exoatmosphere reflectances and at-satellite temperatures. EOSAT Landsat Technical Notes, No. 1. pp. 3-8, Lanham, Maryland.

Scott, J.A. 1986. Butterflies of North America. Stanford University Press, CA 583 pp.

Scott, J.M., F. W. Davis, B. Csuti, R. Noss, B. Butterfield, C. Groves, H. Anderson, S. Caicco, F. D'Erchia, T. C. Edwards Jr., J. Ulliman, and R.G. Wright. 1993. Gap Analysis: A geographic approach to the protection of biological diversity. Wildlife Monographs 123:1-41.

Sokal, R.R. and F.J. Rolf. 1981. Biometry: the Principles and Practice of Statistics in Biological Research. W.H. Freeman and Co.: New York.

Steele, B.B., R.L. Bayn, Jr., and C.V. Grant. 1984. Environmental monitoring using populations of birds and small mammals: Analysis of sampling effort. Biological Conservation 30:157-172. 